\title{
Implant/Abutment Vertical Misfit of One-Piece Cast Frameworks Made with Different Materials
}

\author{
Gustavo Augusto Seabra BARBOSA ${ }^{1}$ \\ Flávio Domingues das NEVES 2 \\ Maria da Gloria Chiarello de MATTOS $^{3}$ \\ Renata Cristina Silveira RODRIGUES ${ }^{3}$ \\ Ricardo Faria RIBEIRO ${ }^{3}$ \\ ${ }^{1}$ Department of Dentistry, Federal University of Rio Grande do Norte, Natal, RN, Brazil \\ ${ }^{2}$ Department of Fixed Prosthodontics, Occlusion and Dental Materials, \\ Federal University of Uberlândia, Uberlândia, $M G$, Brazil \\ ${ }^{3}$ Department of Dental Materials and Prosthodontics, Ribeirão Preto Dental School, \\ University of São Paulo, Ribeirão Preto, SP, Brazil
}

\begin{abstract}
This study compared vertical and passive fit of one-piece cast frameworks made with 3 different materials: commercially pure titanium (CP Ti - G1), cobalt-chromium alloy (Co-Cr - G2) and nickel-chromium-titanium alloy (Ni-Cr-Ti - G3). Fifteen frameworks were obtained simulating bars for fixed prosthesis in a model with 5 implants. The passive and vertical fit of the framework interface was measured using an optical microscope at $\times 30$ magnification. Data were statistically analyzed by ANOVA and LSD tests $(\alpha=0.05)$. Mean and standard deviation values for passive fit and vertical fit were, respectively: G1 [472.49 (109.88) $\mu \mathrm{m}$ and 29.9 (13.24) $\mu \mathrm{m}$ ], G2 [584.84 (120.20) $\mu \mathrm{m}$ and $27.05(10.30) \mu \mathrm{m}]$, and G3 [462.70 (179.18) $\mu \mathrm{m}$ and $24.95(11.14) \mu \mathrm{m}]$. For vertical fit, there were no significant differences among G1, G2 and G3 ( $\mathrm{p}=0.285)$. There were no significant differences for passive fit between G1 and G3 $(p=0.844)$, but both differed significantly from $\mathrm{G} 2(\mathrm{p}=0.028$ and $\mathrm{p}=0.035$, respectively), which showed the highest misfit values. It may be concluded that the vertical fit of frameworks was not affected by the tested materials, and that one-piece cast frameworks resulted in inadequate passive fit. The Co-Cr alloy presented the worst values for passive fit.
\end{abstract}

Key Words: dental implants, prosthesis fixed by implants, prosthesis fit.

\section{INTRODUCTION}

The abutment/implant interface has been reported as a significant factor on stress transfer, adverse biological responses or prosthetic reconstruction complications. Several factors related to implant component manufacturing, as well as the clinical and laboratory phases effect can contribute to a clinical misfit of the prosthesis. In a dental laboratory, each phase (e.g.: casting, soldering, or the combination of both) can result in distortion during prosthesis manufacturing (1).

A framework is considered passive when there is simultaneous circular contact of all the prosthetic cylinders with their respective implant abutments (2). The passive fit is assumed to be one of the most significant prerequisites for the maintenance of the bone-implant interface. To provide passive fit or a strainfree superstructure, a framework should, theoretically, induce absolute zero strain on the supporting implant components and the surrounding bone in the absence of an applied external load (3).

Obtaining a passive fit does not seem to be possible, and it remains as an ideal situation (3). The literature reveals controversy regarding the value of marginal fit that can be called as clinically acceptable (4), especially in one-piece cast frameworks with multiple-units (5).

Several materials have been proposed for the fabrication of implant frameworks. Nonprecious, or base metal alloys are widely used due the low cost, as UCLA castable abutments. Therefore, the aim of this study was to test the hypotheses that the use of different

Correspondence: Prof. Dr. Ricardo Faria Ribeiro, Departamento de Materiais Dentários e Prótese, Faculdade de Odontologia de Ribeirão Preto, USP, Avenida do Café, S/N, 14040-904 Ribeirão Preto, SP, Brasil. Tel: +55-16-3602-4005. Fax: +55-16-3633-0999. e-mail: rribeiro@forp.usp.br 
metallic materials to cast one-piece multi-unit implant frameworks affects the vertical and passive fit.

\section{MATERIAL AND METHODS}

This research was conducted using a metal master model made in brass simulating the curve of a human mandible with five 3.75 x $13 \mathrm{~mm}$ implants (Titamax; Neodent, Curitiba, PR, Brazil). Square transfers were adapted over the implants and bound with dental floss/ acrylic resin (Pattern Resin LS; GC America Inc., Alsip, IL, USA). A custom tray and polyether (Impregum Soft, 3M ESPE, Seefeld, Germany) were used for impression. After material setting, the mold was removed, and titanium implant analogues (Neodent) were adapted to the transfers. The mold was poured to obtain the gypsum master cast (Durone IV; Dentsply, Petrópolis, RJ, Brazil).

Five castable UCLA-type abutments (Neodent) were installed over master model and joined by $5 \mathrm{~mm}$ diameter wax sticks (Dentaurum, Ispringen, Germany) to make 15 similar frameworks. The height of the waxes was standardized at $3 \mathrm{~mm}$ from the gypsum cast and the cantilever length was fixed in $10 \mathrm{~mm}$ to all frameworks. The implants were identified by letters, 'A' and ' $E$ ' being the distal implants. A passive fit test of the waxed frameworks was performed by manually tightening a screw at one end and assessing the fit at the other end. When there were misfits, the wax sticks were cut and joined again with melted wax to correct the inaccuracies. The frameworks were included for casting only at the moment that with one side screwed, misfits were not observed in the others abutments.

The waxed frameworks were randomly arranged into 3 different groups of 5 based on the material to be used to cast them: grade 1 commercially pure titanium (CP Ti - Tritan; Dentaurum); cobalt-chromium alloy (Co$\mathrm{Cr}$ - Remanium 2000; Dentaurum); nickel-chromiumtitanium alloy (Ni-Cr-Ti - Tilite Premium; Talladium Inc., Valencia, CA, USA). Investments compatible with these materials were applied, being Rematitan Plus (Dentaurum) for CP Ti and Castorit super C (Dentaurum) for Co-Cr and Ni-Cr-Ti alloys. According to information provided by the manufacturer, the chemical composition for each one metal alloys is as follows: Tritan (Ti 99.5\%, $\mathrm{Fe}, \mathrm{O}, \mathrm{H}, \mathrm{N}, \mathrm{C}$ ), Remanium 2000 (Co 61\%, Cr 25\%, Mo 7\%, W 5\%) and Tilite Premium (Ni 60-76\%, Cr 12$21 \%$, Mo 4-14\%, Ti 4-6\%). Each group went through casting process in the Discovery Plasma machine (EDG Equipamentos e Controles Ltda., São Carlos, SP, Brazil), which produces electric arc melting in a vacuum and argon-inert atmosphere, with vacuum-pressure alloy injection into the mold. The entire casting process runs automatically and the casting temperature was adjusted according to the manufacturer's guidelines. After casting, the frameworks were divested and airborne-particle abraded with aluminum oxide $\left(\mathrm{Al}_{2} \mathrm{O}_{3}-100 \mu \mathrm{m} ; 80\right.$ lib/in ${ }^{2}$ ), avoiding damage to the abutments seating regions. Sprue formers and small nodules were carefully removed under magnification. No finishing or polishing procedures were performed to ensure uniformity of the frameworks.

Passive fit of the metal frameworks was measured with manual tightening of one screw at a terminal abutment on the master model, standardizing the side of tightening. Non-passive fit was revealed as a gap opening between the framework and the terminal abutment on the other side. The vertical fit were measured in " $y$ " axis with all the screws tightened to a 20 N.cm torque, according to the manufacturer's recommendation. The tightening sequence was standardized from the center to the edges of the piece. A misfit (lack of fit) was present when any of the matching surfaces of the frameworks and abutments were not in contact. All measurements were performed with an optical microscope at $30 \times$ magnification using measurement accuracy of $1 \mu \mathrm{m}$ (Mytutoyo, Tokyo, Japan). An acrylic device was used in order to standardize the position of the master model under the microscope. That device allowed for turning of the master model, making measurement of all implants possible. Two measurements were performed in the mesial and the distal sides of each abutment. The final result was an average of these two measurements, with only one screw tightened (passive fit), and with all screws tightened (vertical fit).

Passive fit and vertical fit values for the different materials were analyzed statistically by ANOVA and least significant difference (LSD) test $(\alpha=0.05)$. Statistical tests were performed with the software SPSS for Windows 12.0 (SPSS Inc., Chicago, IL, USA).

\section{RESULTS}

Table 1 shows the mean values and standard deviations of vertical misfit and passive fit of the 3 analyzed materials. There was no significant differences among the vertical fit values of the tested materials $(p=0.285)$, but significant difference was found for the passive fit values $(\mathrm{p}=0.031)$. 
There were no significant differences for passive fit between CP Ti and Ni-Cr-Ti alloy $(\mathrm{p}=0.844)$, but both were significantly different from Co-Cr alloy ( $\mathrm{p}=0.028$ and $p=0.035$, respectively), which showed the highest misfit values.

\section{DISCUSSION}

Increases in gold prices hastened the transition and led to the development of alternative alloys with base metals (6-8), which contain no gold, silver, platinum or palladium. Nickel and cobalt are the primary metals in most commercially available alloys, with chromium being the next most predominant metal. Chromium increases the resistance of nickel or cobalt alloys to oxidation and also assists in solid solution hardening. Although the good mechanical properties of alternative alloys, nickel is considered a critical metal because there are reports of carcinogenic potential and possible allergic reactions, and chromium has suspected carcinogenicity (7-9). The CP Ti has been widely used because of its excellent properties such as a modulus of elasticity which is closer to that of bone tissue than any other metal and metal alloys, resistance to corrosion and excellent biocompatibility resulting from a surface layer of oxide which is primarily $\mathrm{TiO}_{2}(8)$ and satisfactory results related to implant framework fit $(2,5,10)$. However, titanium requires advanced technology for casting, welding and porcelain bonding. The increase of the use of titanium in prosthodontics depends on research and clinical trials to compare its effectiveness, as equivalent or superior metal, to existing metals $(5,7,8,15)$. Because of this, more studies that confirm equivalence or superiority of this metal in relation to the others are still necessary.

When titanium frameworks were compared to gold alloy, similar vertical fit results were found (10). In relation to passive fit, Sartori et al. (2) obtained similar results to gold alloy only after electroerosion process

Table 1. Mean and standard deviations $(\mu \mathrm{m})$ of vertical misfit and passive fit for the tested materials.

\begin{tabular}{lcccc}
\hline \multirow{2}{*}{ Test type } & \multicolumn{3}{c}{ Materials } & \multirow{2}{*}{$\mathrm{p}$} \\
\cline { 2 - 4 } & $\mathrm{CP} \mathrm{Ti}$ & $\mathrm{Co}-\mathrm{Cr}$ & $\mathrm{Ni}-\mathrm{Cr}-\mathrm{Ti}$ & \\
\hline Vertical Fit & $29.9(13.24)$ & $27.05(10.30)$ & $24.95(11.14)$ & $\mathrm{p}=0.285$ \\
\hline Passive Fit & $472.49(109.88)$ & $584.84(120.20)$ & $462.70(179.18)$ & $\mathrm{p}=0.031^{*}$
\end{tabular}

*Statistically significant difference at $\mathrm{p}<0.05$. of titanium frameworks.

Alternative alloys have been proposed for replacing gold-based alloys $(5,8,9)$. The use of Co$\mathrm{Cr}$ alloys for fabrication of implant frameworks was reported in a clinical study involving 66 patients evaluated the use of $\mathrm{Co}-\mathrm{Cr}$ alloy for implant-supported fixed prosthesis (11). No complications, tissue reactions or framework discoloration were observed after a 3 -year follow-up. According to the authors, $\mathrm{Co}-\mathrm{Cr}$ alloy offers advantages, such as low cost in relation to gold, biocompatibility and resistance to corrosion. However, its hardness makes it difficult to adjust and it has a high modulus of elasticity (11). In the present study, the Co-Cr alloy, when compared with CP Ti and Ni-Cr-Ti alloy, presented the worst results for passive fit, in accordance with other study results $(5,12-15)$. But, for vertical fit, $\mathrm{Co}-\mathrm{Cr}$ alloy was statistically similar to $\mathrm{CP} \mathrm{Ti}$ and $\mathrm{Ni}-\mathrm{Cr}-$ Ti alloy. However, Co-Cr frameworks cast in two pieces and laser welded showed significantly better accuracy in comparison to CP Ti cast in a single piece (12). Further research is necessary to review the use of Co-Cr alloy as an alternative for fabricating implant frameworks.

The Ni-Cr-Ti alloy has been introduced as an alternative to the available materials in relation to surface properties, suggesting that may be considered appropriate for producing abutments (16). When compared the corrosion resistance of $\mathrm{Co}-\mathrm{Cr}, \mathrm{Ni}-\mathrm{Cr}$ and $\mathrm{Ni}-\mathrm{Cr}-\mathrm{Ti}$ alloy in artificial saliva, the $\mathrm{Ni}-\mathrm{Cr}-\mathrm{Ti}$ alloy showed the worst results (17). However, it has been stated that Ni-Cr-Ti alloy provides satisfactory marginal adaptation when used as superstructure for one-piece implant-supported dentures $(9,14,15)$. In the present study, the Ni-Cr-Ti alloy showed no significant differences for passive fit when compared to $\mathrm{CP} \mathrm{Ti}$, both presenting better resulted that the $\mathrm{Co}-\mathrm{Cr}$ alloy. $\mathrm{To}$ vertical fit, the $\mathrm{Ni}-\mathrm{Cr}$-Ti alloy was statistically similar to CP Ti and Co-Cr alloy. Therefore, it could be possible to think about $\mathrm{Ni}-\mathrm{Cr}$-Ti alloys as a viable alternative for implant frameworks.

The passive fit is assumed to be one of the most significant prerequisites for the maintenance of the bone-implant interface. To provide passive fit or a strainfree superstructure, a framework should, theoretically, induce absolute zero strain on the supporting implant components and the surrounding bone in the 
absence of an applied external load $(3,6)$. The clinical and laboratory procedures employed for framework fabrication are inadequate to provide an absolute passive fit for implant-supported fixed superstructures $(3,6)$. All frameworks evaluated in this study showed non-passive fit, confirming the literature report on the difficulty in obtaining one-piece cast frameworks with good marginal fit $(5,14,15)$.

Obtaining a passive fit does not seem to be possible (3). The literature reveals controversy regarding the value of marginal fit that is considered clinically acceptable and shows that measurements of fit implantsupported prostheses reveal significantly different results, depending on whether the prostheses are tried on the master cast or directly in the mouth (4). Some studies, conducted on one-piece cast frameworks with multiple-units considering clinically acceptable values of marginal fit within the $150 \mu \mathrm{m}$ range $(5,6)$. In vivo study on primates found no statistically significant differences in bone response around the implants supporting frameworks with $38 \mu \mathrm{m}$ and $345 \mu \mathrm{m}$ misfits (18). Another in vivo study with aim correlate measurements of prosthesis misfit and change of marginal bone level in implants placed in the edentulous maxilla, observed a mean of misfits of $111 \mu \mathrm{m}$ and $91 \mu \mathrm{m}$ for the 1-year and 5 years groups of follow-up. The authors observed no correlation between change of marginal bone level and different misfits and concluded that the degree of misfit reported in the study was clinically acceptable (19). In the present study, all the frameworks presented values below this range when all screws were tightened. However, the decreased marginal opening from screw tightening can be associated with higher stress in the screw-retained restorations (20). Further studies must be conducted to evaluate the stress.

According of the methodology used, and based on the results obtained, it was possible to conclude that the used materials for frameworks fabrication $(\mathrm{CP} \mathrm{Ti}$, $\mathrm{Co}-\mathrm{Cr}$ and $\mathrm{Ni}-\mathrm{Cr}-\mathrm{Ti}$ ) not influenced the vertical fit and one-piece cast frameworks resulted in inadequate passive fit no matter which material had been used to fabricate them. For the passive fit, the Co-Cr alloy presented the worst results when compared to the $\mathrm{CP} \mathrm{Ti}$ and $\mathrm{Ni}-\mathrm{Cr}$ - $\mathrm{Ti}$ alloys, which showed similar results.

\section{RESUMO}

Este estudo tem como objetivo comparar o ajuste vertical e a passividade de infraestruturas em monobloco confeccionadas em 3 diferentes materiais: titânio comercialmente puro (Ti cp - G1), cobalto-cromo (Co-Cr - G2) e níquel-cromo-titânio (Ni-Cr-Ti - G3). Quinze infraestruturas foram obtidas simulando barras para próteses fixas em um modelo com 5 implantes. $\mathrm{O}$ ajuste vertical e a passividade da interface da infraestrutura foram medidos usando um microscópio óptico $(30 \times)$. Os dados foram analisados estatisticamente por meio da ANOVA e teste LSD $(\alpha=0,05)$. A média dos valores e o desvio-padrão da passividade e do ajuste vertical estão apresentados respectivamente: Ti cp $[472,49(109,88) \mu \mathrm{m}$ e $29,9(13,24) \mu \mathrm{m}]$, Co-Cr $[584,84(120,20)$ $\mu \mathrm{m}$ e $27,05(10,30) \mu \mathrm{m}]$, Ni-Cr-Ti $[462,70(179,18) \mu \mathrm{m}$ e 24,95 $(11,14) \mu \mathrm{m}]$. Para o desajuste vertical, não houve diferença significante entre o Ti cp e as ligas Co-Cr e Ni-Cr-Ti ( $p=0,285)$. Para passividade, não houve diferença significante entre Ti cp e Ni-Cr-Ti $(p=0,844)$, mas ambos foram estatisticamente diferentes do $\mathrm{Co}-\mathrm{Cr}$ ( $\mathrm{p}=0,028 \mathrm{e} \mathrm{p}=0,035$, respectivamente), o qual apresentou os piores resultados. Pode-se concluir que os materiais utilizados para confecção das infraestruturas não influenciaram o ajuste vertical e que infraestruturas fundidas em monobloco resultaram em inadequados ajustes passivos. A liga de $\mathrm{Co}-\mathrm{Cr}$ apresentou os piores resultados para a passividade.

\section{ACKNOWLEDGEMENTS}

This study was financially supported by $\mathrm{CNPq}$ (grant \#305480/2004-9).

\section{REFERENCES}

1. Barbosa GAS, Simamoto Júnior PC, Fernandes Neto AJ, Mattos MGC, Ribeiro RF. Prosthetic laboratory influence on the vertical misfit at the implant/UCLA abutment interface. Braz Dent J 2007; 18:139-143.

2. Sartori IAM, Ribeiro RF, Francischone CE, Mattos MGC. In vitro comparative analysis of the fit of gold alloy or commercially pure titanium implant-supported prostheses before and after electroerosion. J Prosthet Dent 2004;92:132-138.

3. Sahin S, Çehreli MC. The significance of passive framework fit in implant prosthodontics: current status. Implant Dent 2001;10:8592.

4. Jemt T. In vivo measurements of precision of fit involving implantsupported prostheses in the edentulous jaw. Int J Oral Maxillofac Implants 1996;11:151-158.

5. Tossi R, Falcão-Filho H, Aguiar Júnior FA, Rodrigues RC, Mattos $\mathrm{M}$ da G, Ribeiro RF. Modified section method for laser-welding of ill-fitting cp Ti and Ni-Cr alloy one-piece cast implant-supported frameworks. J Oral Rehabil 2010;37:359-363.

6. Spazzin AO, Henriques GEP, Nóbilo MAA, Consani RLX, CorrerSobrinho L, Mesquita MF. Effect of retorque on loosening torque of prosthetic screws under two levels of fit implant-supported dentures. Braz Dent J 2010;21:12-17.

7. Faria ACL, Rodrigues RC, Antunes RP, de Mattos M da G, Rosa $\mathrm{AL}$, Ribeiro RF. Effect of temperature variation on the citotoxicity of cast dental alloys and commercially pure titanium. J Appl Oral Sci 2009;17:421-426.

8. Costa HM, Rodrigues RC, Mattos M da GC, Ribeiro RF. Evaluation of the adaptation interface of one-piece implantsupported superstructures obtained in Ni-Cr-Ti and Pd-Ag alloys. Braz Dent J 2003;14:197-202.

9. Parr GR, Gardner LK, Toth RW. Titanium: the mystery metal of implant dentistry. Dental materials aspects. J Prosthet Dent 1985;54:410-414. 
10. Jemt T. Three-dimensional distortion of gold alloy castings and welded titanium frameworks. Measurements of the precision of fit between completed implant prostheses and the master casts in routine edentulous situations. J Oral Rehabil 1995;22:557-564.

11. Hulterström M, Nilsson U. Cobalt-chromium as a framework material in implant-supported fixed prostheses: a preliminary report. Int J Oral Maxillofac Implants 1991;6:475-480.

12. Koke $\mathrm{U}$, Wolf A, Lenz $\mathrm{P}$, Gilde H. In vitro investigation of marginal accuracy of implant-supported screw-retained partial dentures. J Oral Rehabil 2004;31:477-482.

13. Kano SC, Binon PP, Bonfante G, Curtis DA. The effect of casting procedures on rotational misfit in castable abutments. Int J Oral Maxillofac Implants 2007;22:575-579.

14. Torres EM, Rodrigues RCS, Mattos MGC, Ribeiro RF. The effect of commercially pure titanium and alternative dental alloys on the marginal fit of one-piece cast implant frameworks. J Dent 2007;35:800-805.

15. Tiossi R, Rodrigues RC, Mattos M da GC, Ribeiro RF. Comparative analysis of the fit of 3-unit implant-supported frameworks cast in nickel-chromium and cobalt-chromium alloys and commercially pure titanium after casting, laser welding, and simulated porcelain firings. Int J Prosthodont 2008;21:121-123.

16. Lima EM, Silva WJ, Moura JS, Faot F, Del Bel Cury AA. Evaluation of surface characteristics of Ti-6Al-4V and Tilite alloys used for implant abutments. Braz Oral Res 2006;20:307-311.

17. Sun $\mathrm{P}, \mathrm{Lu} \mathrm{Y}$, Chen S. Corrosion resistance of $\mathrm{Co}-\mathrm{Cr}$, Ni-Cr, Ni-Cr-Ti alloy in artificial saliva. Shanghai Kou Qiang Yi Xue 2007; 16:652-656.

18. Carr AB, Gerard DA, Larsen PE. The response of bone in primates around unloaded dental implants supporting prostheses with different levels of fit. J Prosthet Dent 1996;76:500-509.

19. Jemt T, Book K. Prosthesis misfit and marginal bone loss in edentulous implant patients. Int J Oral Maxillofac Implants 1996;11:620-625.

20. Guichet DL, Caputo AA, Choi H, Sorensen JA. Passivity of fit and marginal opening in screw- or cement-retained implant fixed partial denture designs. Int J Oral Maxillofac Implants 2000;15:239-246.

Accepted November 9, 2010 